\title{
Educational interventions to reduce childhood antibiotic prescribing for upper respiratory infections: systematic review and meta-analysis
}

AUTHORS: Yanhong Hu, M.D, MPH, ${ }^{\mathrm{a}}$ John Walley FFPH, MComH,${ }^{\mathrm{b}}$ Roger Chou, MD, ${ }^{\mathrm{c}}$ Joseph D Tucker, MD, PhD, ${ }^{\mathrm{d}}{ }^{\mathrm{J}}$ oseph I Harwell, M.D, FAAP, FIDSA, ${ }^{\mathrm{e}}$ Xinyin Wu, PhD, ${ }^{\mathrm{a}} \mathrm{Jia}$ Yin, MPH, ${ }^{\mathrm{a}}$ Guanyang Zou, MPHil, Xiaolin Wei PhD, FFPH. ${ }^{\text {ga }}$

${ }^{a}$ The Jockey Club School of Public Health and Primary Care, The Chinese University of Hong Kong (CUHK), Hong Kong, China

${ }^{\mathrm{b}}$ International Public Health, COMDIS-HSD, Nuffield Centre for International Health, LIHS, University of Leeds, Leeds, UK

${ }^{\mathrm{c}}$ Medical Informatics \& Clinical Epidemiology, Oregon Health \& Science University, USA

${ }^{\mathrm{d}}$ UNC Project-China, Guangzhou, China and International Diagnostics Centre, London School of Hygiene and Tropical Medicine, London, UK

${ }^{\mathrm{e}}$ Clinton Health Access Initiative, 383 Dorchester Avenue, Suite 400, Boston, MA 02127, USA

${ }^{f}$ Nuffield Centre for International Health and Development, University of Leeds, UK (Based in China), Shenzhen, China

${ }^{\mathrm{g}}$ Dalla Lana School of Public Health, University of Toronto, 155 College Street, Ontario, M5T 3M7, Canada

\section{KEYWORDS}

Educational intervention, childhood upper respiratory infection, antibiotic prescription, systematic review, Meta-analysis
ABBREVIATIONS
URIs-upper respiratory infections
RCTs-randomized controlled trials
APR-antibiotics prescription rate
OR-Odds Ratio
CI-confidence interval
ICC- intra-cluster correlation coefficients

Dr. Yanhong Hu designed the study, screened the candidate papers, extracted and analyzed data, wrote the manuscript and approved the final manuscript as submitted. Prof. John Walley wrote the manuscript, interpreted the data and approved the final manuscript. Prof Joseph I Harwell wrote the manuscript, interpreted the data and approved the final manuscript. Prof. Roger Chou reviewed the revised manuscript and approved the final manuscript as submitted. Prof. Joseph D Tucker reviewed the revised manuscript and approved the final manuscript as submitted. Mr. Guangyang reviewed the revised the manuscript and approved the final manuscript as submitted. Dr. Xinyin Wu reviewed the revised the manuscript and approved the final manuscript as submitted. Ms. Jia Yin reviewed the revised the manuscript and approved the final manuscript as submitted. Prof. Xiaolin Wei designed the study, extracted data, analyzed and interpreted the results, wrote the manuscript and approved the final manuscript as submitted.

Address correspondence to Prof. Xiaolin Wei, PhD, FFPH, Dalla Lana School of Public Health, University of Toronto, 155 College Street, Ontario, M5T 3M7, Canada.Email: xiaolin.wei@utoronto.ca.

FINANCIAL DISCLOSURE: The authors have no financial relationships relevant to this article to disclose.

FUNDING: MRC welcome trust - Funding reference number: MR/M022161/1.

PROSPERO registration number: CRD42015029255. (http://www.crd.york.ac.uk/PROSPERO) 
CONFLICT OF INTEREST: The authors declare that there are no conflicts of interest.

\begin{abstract}
Context

Antibiotics are over-prescribed for children with upper respiratory infections (URIs), leading to unnecessary expenditures, adverse events and antibiotic resistance.
\end{abstract}

\title{
Objective
}

To assess whether interventions can reduce antibiotic prescription for childhood URIs and identify what factors impact intervention effectiveness.

\section{Data sources}

MEDLINE, EMBASE, Google Scholar, Web of Science - Global Health, WHO website, United States CDC website and The Cochrane Central Register of Controlled Trials (CENTRAL) were searched by August 2014.

\section{Study selection}

Cluster or individual patient randomized controlled trials (RCTs) and non-randomized controlled trials examining interventions to change antibiotic prescription rates (APR) for children with URIs were selected for meta-analysis. Educational interventions for clinicians and/or parents were compared with usual care.

\section{Results}

Of 6074 studies identified, thirteen were included. All were conducted in high-income countries. Educational interventions were associated with lower APR versus usual care (OR 0.65 (95\% confidence interval [CI] 0.49$0.86, \mathrm{P}<0.001)$. A patient-clinician communication approach was the most effective type of intervention, with a pooled OR $0.41(95 \%$ CI $0.20-0.83 ; \mathrm{P}<0.001)$ for clinicians and a pooled OR for parents $0.26(95 \%$ CI $0.08-0.91$; $\mathrm{P}=0.04)$ compared with usual care. Compared with usual care, educational interventions that targeted both clinicians and parents were more effective than interventions for either group alone OR of 0.52 (95\% CI 0.35 $0.78 ; \mathrm{P}=0.002)$.

\section{Conclusion}

Educational interventions are effective in reducing antibiotic prescribing for childhood URIs. Interventions targeting both clinicians and parents are more effective than those for either group alone. The most effective interventions address patient-clinician communication. Studies in low-middle income countries are needed.

Word (249) 


\section{Introduction}

Worldwide, inappropriate medication use is a major problem. According to the World Health Organization (WHO) $50 \%$ of medicines are prescribed, dispensed or sold inappropriately, while $50 \%$ of patients take their medicines incorrectly. ${ }^{1}$ Inappropriate antibiotic use can lead to antibiotic resistance, resulting in difficult or impossible to treat infections. ${ }^{2}$ Antibiotic resistance is more common in countries with high rates of antibiotic prescription. $^{2}$

Childhood upper respiratory infections (URIs) are very common, but are usually viral and self-limiting. Nevertheless prescribing antibiotics for childhood URIs is highly prevalent. ${ }^{3}$ Antibiotic resistance is frequently observed in young children and more invasive infections occur in this vulnerable population. ${ }^{4}$ In Asia, every two minutes a child under five years of age dies from antibiotic-resistant infections. ${ }^{5}$

There are two main factors influencing inappropriate antibiotic use for childhood URIs - clinician prescribing and parent knowledge, attitude and demand. ${ }^{6}$ Educational interventions addressing these factors could reduce inappropriate antibiotic use. A Cochrane review showed that interventions involving physicians/pharmacists could reduce antibiotic prescription rates. ${ }^{7}$ However this review did not assess specifics of interventions (e.g., intervention type, the intervention target, intensity). Conflicting results were seen with parental interventions. One review found that parental interventions can influence knowledge and behavior, reducing consultation rates by $13 \%$ to $40 \%{ }^{3}$ However, another review showed that caregiver education may not be effective. ${ }^{8}$ Many published studies are descriptive, involving both adults and children with various diseases. ${ }^{9-12}$ This study aims to analyze the effectiveness of different intervention approaches, targeting different groups (clinicians, parents or both) and whether other factors - study setting, study design, study period - influence effectiveness for reducing antibiotic prescribing for childhood URIs. 


\section{Methods}

Search strategy

We searched MEDLINE, EMBASE, Google scholar, Web of Science, Global Health, WHO website, United States CDC website and The Cochrane Central Register of Controlled Trials (CENTRAL) from 1980 to December 2015 for published articles without language restriction. Search terms included URIs, respiratory infections (RI), education, antibiotic prescription/prescribing, children/pediatric and antibiotic prescription rates. Two independent reviewers screened candidate studies using a structured form based on the PRISMA 2009 four-phase flow diagram.

\section{Study selection}

We included studies according to PICOS (population, intervention, comparison, outcome, setting) characteristics by following professional interventions in the Effective Practice and Organization of Care group (EPOC) scope. ${ }^{13}$

Population We included studies of children ( $<=18$ years of age) diagnosed with any URI including rhinitis, sinusitis, pharyngitis, tonsillitis, acute otitis media or URI as a general category. To reduce misclassification bias, for studies that classified URI and these aforementioned specific categories as separate, we included all patients as they should be classified under the category of "URI" in our analysis.

Intervention - Approaches for targeting clinicians, featuring: 1) Antibiotic prescription rate (APR) feedback; 2) Update and/or reinforcement of national guidelines; 3) Promoting delayed prescriptions; 4) Clinician-parent communication skills training and workshops. Intervention methods included: 1) Face to face training such as seminars, workshops or group discussion by trained peer leaders; 2) Indirect training, which included online workshops or pop-up messages through software or printed information related to appropriate antibiotic use. Approaches for targeting parents included: 1) Printed educational materials including leaflets/pamphlet or 
posters; 2) Mass media such as video, radio and newspapers; 3 ) Clinician-patient communication, which included facilitating patient health literacy, explaning appropriate antibiotic use by clinicians.

Comparator We included prospective studies with an intervention group compared to a control with usual care. Study designs were (clustered) randomized controlled trials and non-randomized controlled trials including cohort experimental studies.

Outcome Studies with antibiotic prescription expressed either as a rate (\%) or as numbers per person-time were included. APR was defined as the number of children who were prescribed one or more antibiotic classes divided by the total number of children assessed for URIs during a designated interval.

Setting Studies from all geographic regions were eligible for inclusion. Study sites were included if they cared for children either in primary care/general practice or in specialty clinics.

\section{Quality assessment}

Quality was determined by two independent reviewers using the Cochrane risk of bias tool ${ }^{13}$, including domains related to sequence generation, allocation concealment, blinding, incomplete outcome data, selective reporting, intervention contamination, seasonal data collection and reporting of clustering coefficient. Each item outcome was categorized as high risk, low risk or unclear risk according to information provided. Disagreements between reviewers were resolved by discussion and consensus.

\section{Data extraction}

For the characteristic table, we extracted the following variables: study design, setting, follow up duration, children age, participants, details of interventions (target group, intervention content for clinician and parents, intervention technics), details of the comparator and outcome measures. To calculate the intervention group APR odds ratio (OR) we extracted the number of children or visits prescribed any antibiotic from both groups 
as well as the total number of children or visits in each group. For studies that were designed as cluster randomized controlled trials (RCTs), we also extracted the intra-cluster correlation coefficients (ICCs) to adjust for design effect according to the Cochrane handbook. ${ }^{13}$ Furthermore, for studies with unknown ICC, we estimated from similar trials or by an approximated ICC. ${ }^{13}{ }^{14}$ Studies with more than one control or time point were treated as if controls and time points were independent of each other. ${ }^{15}$

\section{Analysis}

Only studies with a calculable or reported APR were included into the meta-analysis. OR and 95\% confidence interval (CI) were used to measure the effectiveness of intervention compared to usual care. Overall $p$ value was used for the interaction between intervention and the estimates. We pooled studies using a Bayesian randomeffects model to account for variations across RCTs in populations, interventions, settings and other factors during meta-analyses. ${ }^{16}{ }^{17}$ Heterogeneity across studies was evaluated using the $\mathrm{I}^{2}$ test. To explore heterogeneity source, meta-regressions were conducted for each potentially influential factor (target group, follow-up duration, region, design, year). For cluster studies additional factors (ICC reported or unreported, number of clusters, whether sites were pediatric clinics) were included. We also conducted a sensitivity analysis on individual studies to identify potential effects of outliers. For studies designed as cluster RCTs, we conducted another sensitivity analysis on ICC factors to determine if design effect influenced study outcome. According to the Cochrane handbook we selected three different ICC values $(0.004,0.02$ and 0.2$)$ for this sensitivity analysis. [18] For studies with more than one control group and time point within a study we also compared the result by merging effects within each study. ${ }^{15}$ Finally, we used a funnel plot with Egger's regression test to assess for publication bias $(\mathrm{p}<0.1)$. All analyses used STATA version 13 .

\section{Results}

Description of included interventions 
Of 6074 articles, 373 were accessed with full text. After exclusions 12 articles were eligible for meta-analysis (see Figure 1).

Of the 12 studies included into this systematic review and meta-analysis, seven were cluster RCTs, three were non-randomized controlled trials and two were individual RCTs. One study had two control groups; one had 4 outcomes with 3 different follow-up durations and one follow-up (12 months, 24 months, 36 months, 48 months). Six studies were conducted in the United States (US), two in Israel, two in Norway, and one each in United Kingdom (UK), Iran, and Canada. Eight of 12 were conducted in primary care or general practices and the remaining four studies were conducted in pediatric practices. The study year ranged from 2000 to 2014 , with follow-up duration lasting from one to 12 months. Finkelstein $2001^{18}$ had two outcomes for age 3-36 months and 36-72 months. Gonzales $2005^{19}$ had two control groups with one located near to the intervention site and the other far from it. Regev-Yochay $2011^{20}$ had 4 time point outcomes for different intervention types year one was workshops for determinants of reducing antibiotic prescriptions, year two focused on patientclinician communication, year three involved workshops for APR feedback and year four was for follow-up after intervention. The cluster numbers ranged from two to 286 units, and the number of participating clinicians and registered patients ranged from 27 to 578 and 81 to 97699, respectively (Table 1). Nine articles were found to have low risk of bias, three had high risk (see Table 2).

\section{Intervention effects, all studies (Figure 2)}

Based on heterogeneity we used random-effects to deal with differences among studies. We combined the control groups and combined the different time point outcomes within studies. The pooled OR of APR for the intervention group was 0.65 (95\% CI 0.49-0.86; $\mathrm{P}=0.003)$. However, significant heterogeneity was observed $\left(\mathrm{I}^{2}=66 \%\right)$ as a result of differences in design, population, and intervention details.

\section{Effects of intervention strategies (Figure 3)}


Among the clinician interventions four of nine studies used guidelines for respiratory infections and two used APR feedback to clinicians. Delayed prescription was used in one study. Three studies used patient-clinician communication skills training. Training and workshops lasted from 40 minutes to two days. Training lasted $<1$ day in 6 studies and $>1$ day for the remaining 3. Printed leaflets/posters were used in three of eight studies involving parents. Three studies used patient-clinician communication intervention. Two studies used video in waiting areas, lasting five to eight minutes.

Meta-analysis showed that the pooled OR for all types of interventions with clinicians was 0.65 (95\% CI 0.54 $\left.0.79 ; \mathrm{I}^{2}=44 \%\right)$, for patient-clinician communication approach was $0.41\left(95 \%\right.$ CI $\left.0.20-0.83 ; I^{2}=73 \%\right)$, for APR feedback was $0.65\left(95 \%\right.$ CI $\left.0.49-0.87 ; I^{2}=0 \%\right)$, for delayed prescription was $0.86(95 \%$ CI $0.65-1.13 ; n=1)$, for guideline use was $0.68\left(95 \%\right.$ CI $\left.0.53-0.88 ; \mathrm{I}^{2}=21 \%\right)$. Though there were overlaps in $95 \% \mathrm{CI}$, testing for subgroup interaction was insignificant $(\mathrm{p}=0.2)$.

For intervention types with parents, the pooled OR for all was $0.55\left(95 \% \mathrm{CI} 0.36-0.84 ; \mathrm{I}^{2}=36 \%\right)$, for video was $0.86\left(95 \%\right.$ CI $\left.0.56-1.31 ; \mathrm{I}^{2}=0 \%\right)$, for leaflets/posters the pooled OR was $0.74\left(95 \%\right.$ CI $\left.0.49-1.12 ; \mathrm{I}^{2}=0 \%\right)$, for patient-clinician conmmunication was $0.26\left(95 \%\right.$ CI $\left.0.08-0.91 ; \mathrm{I}^{2}=86 \%\right)$. No significant subgroup difference was found.

Effects of interventions through targeted group, study design, study year, follow-up duration and intensity of intervention and ICC report (Table 3)

When studies were grouped according to the intervention target, four studies targeting clinicians achieved a pooled OR of $0.88\left(95 \%\right.$ CI $\left.0.67-1.16 ; \mathrm{I}^{2}=73 \%\right)$. Three studies targeting parents achieved an OR of $0.50(95 \%$ CI $0.10-2.51 ; \mathrm{I}^{2}=80 \%$ ). A total of five studies that had interventions targeting both groups achieved a pooled OR of $0.52\left(95 \%\right.$ CI $\left.0.34-0.79 ; \mathrm{I}^{2}=50 \%\right)$.

For studies with different designs, the pooled OR for all RCTs (including cluster RCTs) was 0.56 (95\% CI 0.41 0.78; $\left.\mathrm{I}^{2}=74 \%\right)$. Non-randomized controlled trials had similar pooled OR $0.84\left(95 \% \mathrm{CI} 0.61-1.17 ; \mathrm{I}^{2}=0 \%\right)$. Five 
studies were conducted in 2010s and seven were in 2000s. The pooled OR was for studies conducted in 2000s was $0.59\left(95 \%\right.$ CI $\left.0.36-1.00 ; \mathrm{I}^{2}=66 \%\right)$ and for studies in 2010 s was $0.66\left(95 \%\right.$ CI $\left.0.49-0.89 ; \mathrm{I}^{2}=72 \%\right)$.

For studies with different follow-up durations, six had follow-up durations from 1-6 months, with a pooled OR of $0.62\left(95 \%\right.$ CI $\left.0.43-0.90, I^{2}=77 \%\right)$ while the pooled OR for the other six studies with follow-up durations from 7-12 months was $0.59\left(95 \%\right.$ CI $\left.0.45-0.79, \mathrm{I}^{2}=17 \%\right)$. For the nine face to face training studies the pooled RR was 0.77 (95\% CI 0.65-0.92; $\mathrm{I}^{2}=36 \%$ ), while three studies with written or online training had a pooled OR of 0.38 (95\% CI 0.21-0.70; $\left.\mathrm{I}^{2}=44 \%\right)$. However subgroup interaction here was significant $(\mathrm{p}=0.03)$.

When evaluating only cluster trials, the results were similar to including all studies. Studies that reported ICC achieved a pooled OR $0.52\left(\mathrm{n}=4,95 \%\right.$ CI $\left.0.33-0.84 ; \mathrm{P}=0.007 ; \mathrm{I}^{2}=76 \%\right)$ while studies with unreported ICC had a higher OR $0.81\left(\mathrm{n}=5,95 \%\right.$ CI $\left.0.67-0.98 ; \mathrm{I}^{2}=13 \%\right)$. Pediatric clinical settings achieved a pooled OR of $0.61(95 \%$ CI $\left.0.47-0.79 ; \mathrm{I}^{2}=0 \%\right)$, which was similar to non-pediatric settings $0.60\left(95 \%\right.$ CI $\left.0.43-0.85 ; \mathrm{I}^{2}=74 \%\right)$.

\section{Meta regression}

To explore factors that might contribute to heterogeneity between studies, we also conducted meta-regressions on target group, follow-up duration, study design, study setting and study years, respectively for all included studies. However, none of these factors were associated with between-study heterogeneity. Also when only considering cluster studies, none of these variables or additionally, ICC reported or unreported or study setting were associated with between-study heterogeneity.

\section{Sensitivity analysis}

We used three different ICCs to assess all cluster studies $(\mathrm{ICC}=0.04 ; \mathrm{ICC}=0.02 ; \mathrm{ICC}=0.2)$ without a reported ICC according to the following factors: target of intervention, study design, follow-up duration and study year for all studies and only cluster studies. Results were consistent across the three ICCs.

Sensitivity analysis on individual studies revealed that there was no change in heterogeneity after omitting any of the included articles. 


\section{Publication bias}

Results from Egger's regression test revealed publication bias was not significant $(p=0.214)$

\section{Discussion}

We have found that clinician-parent communication intervention appeared to have the strongest effect compared to other approaches. APR feedback and updated guidelines were effective in reducing APR for childhood URIs. Targeting both clinicians and parents was more effective compared with targeting either group alone. Among cluster trials, those with reported ICC had a stronger effect. None of the following factors: intervention target, follow-up duration, design, years, clinical setting, and reported or unreported ICC were associated with residual variation due to heterogeneity. This is probably due to the presence of multiple sources of heterogeneity as well as difficulty in measuring sources of heterogeneity. However, heterogeneity declined by subgroup, with heterogeneity for intervention with clinicians at $44 \%$ while that for interventions with parents was $36 \%$.

Previous systematic reviews were conducted to explore the effectiveness of interventions to reduce irrational antibiotic prescription in both adults and children with various diseases. ${ }^{34721-24}$ The advantages of our review over others is that we focus on a specific population (children) and condition (URI) and stratified analyses according to the type of intervention, which enriched the existing literature as most of the previous studies were descriptive. Additionally, very few studies describe intervention approaches. We found that the lowest pooled ORs were seen in the clinician-parent communication approach, This is consistent with the review by Davey ${ }^{11}$ et al for hospital inpatients. Davey found that clinician-targeted intervention using interactive meetings appeared more effective than didactic lectures, improved laboratory resources and consultation with specialists.

Combined interventions were found to be more effective than a single intervention alone 7222526 . This review and prior research reached similar conclusions, in particular that the involvement of both physicians and parents was most effective. Vodicka ${ }^{24}$ and Boonacker ${ }^{26}$ both examined interventions to improve childhood antibiotic 
prescription for respiratory infections. However, neither review used meta-analysis to measure relative risk. Both concluded that multifaceted interventions can reduce antibiotic use, however providing printed materials and targeting only parents had limited effects, which is consistent with our results. A review conducted by Thoolen showed that education to decrease inappropriate antibiotic use was not effective despite increased patient knowledge, which is contrary to the findings from Arnold ${ }^{7}$ and our analysis. We found the pooled OR for targeting parents was 0.50 though it was statistically insignificant with a higher $\mathrm{I}^{2}$. In these studies, the change in knowledge was the primary outcome, while very few studies had data for APR that could be included into the meta-analysis. Nevertheless education for parents could have a synergistic effect with clinician training and further reduce APR. ${ }^{28}$

For cluster RCTs, within-study variation can also influence the effect through variation at the cluster level. ${ }^{29} \mathrm{We}$ observed a stronger effect in studies where ICC was reported. A study that reports the ICC may have been more carefully designed with more consideration of study design.

Our review has several strengths. First, to our knowledge, this is the first study to examine the effect of interventions through APR, which is ultimately the desired effect. Second, sensitivity analysis with 3 different ICC found trends to be consistent. Sensitivity analysis on excluding cluster non-randomized controlled trails had similar results, suggesting the study design had limited effect on the results. This suggests results were reliable. Third, the two studies with the widest confidence intervals targeted both clinicians and parents, and both were cluster RCTs. This may actually have led to under-estimation of the effect of this type of intervention, making the result more conservative. Fourth, we evaluated the association between interventions and APR under subgroups of 1) different approaches to clinicians and parents respectively;2) study design and 3) study settings rather than just the overall effect, thus making our findings more specific.

In terms of limitations, Firstly, non-randomized controlled trials had a higher selection bias than RCTs, while cluster RCTs had cluster level selection bias, although we calculated the cluster RCT studies ICC to adjust for design effects. It is impossible to avoid the nature of the existing selection bias within studies. Secondly, most of 
the studies we reviewed had multifaceted interventions, which were mixed to maximize the effect, making it difficult to evaluate individual components. At the same time, prescription is not a single clinician behavior, but is influenced by different factors. This also increases the complexity of study design, which made data analysis complex and we could not analyze which intervention component is superior to the other. As no study provided feedback on the intervention implementation, it is difficult to know which component might contribute the most. Thirdly, no study was from a developing country, which limits generalizability.

For policy makers, we hope we have better characterized the optimal intervention design. Future efforts should focus on an interactive approach that includes both parents and clinicians, in addition to providing clinicians with information through feedback on their APR and guidelines. Communications skills between clinicians and parents should also be enhanced. Education for parents might facilitate improved communication.

Future studies of the quality of intervention implementation are needed. Given the variability in the content and intensity of a given type of intervention, more research is needed to understand optimal content/intensity. This is needed for children especially, given the frequency of URI in this population and the paucity of available proven therapies. There is a need to evaluate future interventions in the context of continuously improving diagnostics and therapeutics. More evidence on intervention sustainability is needed and the acceptance of interventions should be further explored based on the local context, resources and cost-effectiveness studies. The interventions in these trials should be studied against a theoretical framework of health behavior change. Given the extent of antibiotic overuse in developing countries, further studies of interventions in these settings are needed.

\section{Words (3024)}

\section{Acknowledgements}


We thank Yiwen Huang the former research assistant from COMDIS-HSD, Nuffield Centre for International Health Shenzhen office for the contribution to literature review and earlier version of drafting, Professor Robbie Foy from Leeds Institute of Health Science, University of Leeds and Dr. Rebecca King from Nuffield Centre for International Health and Development, University of Leeds for their comments and reviews of this manuscript. 


\section{What is already known on this subject?}

Antibiotic resistance is a global public health crisis, due in part to over-prescribing of antibiotics, which is common for childhood URIs. Systematic reviews show interventions with providers

reduce antibiotic prescription, but with conflicting results about interventions with parents. Little is known about the relative benefits of each intervention, and no meta-analyses have been

published.

\section{What the study adds:}

In order to reduce antibiotic prescription for childhood URIs, the most effective interventions involve both clinicians and parents. Improved communication between clinicians and parents is an essential part of antibiotic stewardship for childhood URIs.

Table 1. Basic characteristics of the included studies $(n=12)$

\begin{tabular}{|c|c|c|c|c|c|c|c|c|}
\hline Study ID & Design & $\begin{array}{l}\text { Settings/ } \\
\text { No of } \\
\text { clusters }\end{array}$ & $\begin{array}{l}\text { Follow-up } \\
\text { duration }\end{array}$ & $\begin{array}{l}\text { Children } \\
\text { age }\end{array}$ & Participants & Intervention & Control & Outcomes \\
\hline Esmaily $2010^{* \# 31}$ & cRCT & $\begin{array}{l}\text { Iran/ } \\
110 \\
\text { clusters }\end{array}$ & 3 months & $\begin{array}{l}\text { Not } \\
\text { described }\end{array}$ & $\begin{array}{l}112 \text { general } \\
\text { practitioners } \\
\text { (GPs) }\end{array}$ & $\begin{array}{l}\text { Target: Clinicians } \\
\text { Approach: peer leaders } \\
\text { training } \\
\text { Content: } \text { principle of } \\
\text { rational antibiotic use } \\
\text { (guideline) } \\
\text { Technic: } 16 \text { hours workshop }\end{array}$ & $\begin{array}{l}\text { Control: lecture based } \\
\text { training with } \\
\text { traditional teaching } \\
\text { method }\end{array}$ & $\begin{array}{l}\text { \% prescriptions with antibiotics } \\
\text { intervention: } 61 \% \text { to } 63 \% \\
\text { Control: } 59 \% \text { to } 60 \%\end{array}$ \\
\hline $\begin{array}{l}\text { Finkelstein } \\
2001^{* \# 18} \text { (outcome } \\
\text { for age } 3-36 \\
\text { months, outcome } \\
\text { for } 36-72 \text { months }\end{array}$ & cRCT & $\begin{array}{l}\text { US/ } \\
12 \text { clusters }\end{array}$ & 12 months & $\begin{array}{l}3 \text { months } \\
\text { to } 72 \\
\text { months }\end{array}$ & $\begin{array}{l}157 \text { practice } \\
\text { clinicians; } \\
13460 \\
\text { patients }\end{array}$ & $\begin{array}{l}\text { Target: } \text { Both clinicians and } \\
\text { parents } \\
\text { Approach } \\
\text { to clinicians: update } \\
\text { guideline, peer leaders } \\
\text { training } \\
\text { to parents: leaflets/posters; }\end{array}$ & $\begin{array}{l}\text { No educational } \\
\text { intervention and no } \\
\text { feedback }\end{array}$ & $\begin{array}{l}\text { The rate of antimicrobial prescribing per } \\
\text { person year in the Intervention: decreased } \\
\text { by } 41 \% \\
\text { control: decreased by } 33 \%\end{array}$ \\
\hline
\end{tabular}




\begin{tabular}{|c|c|c|c|c|c|c|c|c|}
\hline & & & & & & $\begin{array}{l}\text { Technic: } 90 \text { minutes' small } \\
\text { group education }\end{array}$ & & \\
\hline Francis $2009 * 32$ & cRCT & $\begin{array}{l}\mathrm{UK} / \\
61 \text { clusters }\end{array}$ & 7 months & $\begin{array}{l}6 \text { months } \\
\text { to } 14 \\
\text { years }\end{array}$ & $\begin{array}{l}108 \text { practice } \\
\text { clinicians; } \\
558 \text { patients }\end{array}$ & $\begin{array}{l}\text { Target: Both clinicians and } \\
\text { parents } \\
\text { Approach to both: } \\
\text { Content: patient-clinician } \\
\text { communication } \\
\text { Technic : } 40 \text { minutes online } \\
\text { training }\end{array}$ & Usual care & $\begin{array}{l}\text { Antibiotics were prescribed at the index } \\
\text { consultation } 19.5 \% \text { in the intervention } \\
\text { group and } 40.8 \% \text { in the control group }\end{array}$ \\
\hline Gerber 2013*\#33 & cRCT & $\begin{array}{l}\text { US/ } \\
18 \text { clusters }\end{array}$ & 12 months & $1-10$ years & $\begin{array}{l}162 \text { practice } \\
\text { clinicians }\end{array}$ & $\begin{array}{l}\text { Target: Clinicians } \\
\text { Content: updated } \\
\text { guidelines; APR feedback } \\
\text { Technic: } 1 \text { hour clinical } \\
\text { training }\end{array}$ & $\begin{array}{l}\text { No education and } \\
\text { prescribing } \\
\text { feedback }\end{array}$ & $\begin{array}{l}\text { For acute sinusitis broad spectrum } \\
\text { prescriptions in intervention: decreased } \\
\text { from } 38.9 \% \text { to } 18.8 \% \\
\text { Control: decreased from } 40.0 \% \text { to } 33.9 \%\end{array}$ \\
\hline Gjelstad 2013*34 & cRCT & $\begin{array}{l}\text { Norway/ } \\
79 \text { clusters }\end{array}$ & 6 months & $<18$ years & $\begin{array}{l}382 \text { practice } \\
\text { clinicians }\end{array}$ & $\begin{array}{l}\text { Target: Clinician } \\
\text { Approach: peer leaders } \\
\text { training; } \\
\text { Content: Delayed } \\
\text { prescriptions } \\
\text { Technic:One day seminar }\end{array}$ & $\begin{array}{l}\text { Control: received } \\
\text { intervention targeting } \\
\text { appropriate drug use } \\
\text { but not antibiotics }\end{array}$ & $\begin{array}{l}\text { APR: Intervention: decreased from } \\
33.2 \% \text { to } 31.85 \text { Control: increased from } \\
33.4 \% \text { to } 35 \%\end{array}$ \\
\hline $\begin{array}{l}\text { Gonzales } \\
2005^{19} \text { (two control } \\
\text { groups) }\end{array}$ & 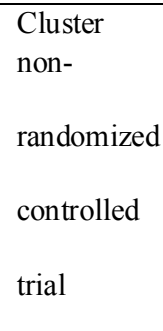 & $\begin{array}{l}\mathrm{US} / \\
7 \text { clusters }\end{array}$ & 3 months & $0-17$ years & $\begin{array}{l}578 \text { practice } \\
\text { clinicians }\end{array}$ & $\begin{array}{l}\text { Target: Both Clinician and } \\
\text { parents } \\
\text { Approach } \\
\text { to clinicians: Content: } \\
\text { APR feedback, } \\
\text { to parents: Leaflets/posters } \\
\text { Technic: } \text { Mail the } \\
\text { information }\end{array}$ & $\begin{array}{l}\text { Physician education } \\
\text { only, two controls: } \\
\text { local and distance } \\
\text { practices }\end{array}$ & $\begin{array}{l}\text { Adjusted antibiotic prescription rates: } \\
\text { Distant control increased from } 38 \% \text { to } \\
39 \% \\
\text { Local control decreased from } 39 \% \text { to } \\
37 \% \\
\text { Intervention decreased from } 34 \% \text { to } 30 \%\end{array}$ \\
\hline Juzych $2005^{35}$ & $\begin{array}{l}\begin{array}{l}\text { Cluster } \\
\text { non- } \\
\text { randomized }\end{array} \\
\text { controlled } \\
\text { trial }\end{array}$ & $\begin{array}{l}\text { US/ } \\
4 \text { clusters }\end{array}$ & 5 months & $<15$ years & $\begin{array}{l}30 \text { clinic } \\
\text { physicians; } \\
15 \text { internists }\end{array}$ & $\begin{array}{l}\text { Target: Clinician } \\
\text { Approach: Content: clinical } \\
\text { guideline; } \\
\text { Technic: half day education }\end{array}$ & $\begin{array}{l}\text { No educational } \\
\text { interventions }\end{array}$ & $\begin{array}{l}\text { Change in antibiotic prescription rate in } \\
\text { Intervention: reduced by } 35.2 \% \\
\text { Control: increased by } 6.5 \%\end{array}$ \\
\hline Legare $2012 * 36$ & cRCT & $\begin{array}{l}\text { Canada/ } \\
9 \text { clusters }\end{array}$ & 5 months & $\begin{array}{l}8 \text { months - } \\
9 \text { years }\end{array}$ & $\begin{array}{l}149 \\
\text { physicians; } \\
359 \text { eligible }\end{array}$ & $\begin{array}{l}\text { Target: } \text { Both clinician and } \\
\text { parents } \\
\text { Approach: peer leaders } \\
\text { training; Patient-clinician }\end{array}$ & Usual care & $\begin{array}{l}\% \text { patients deciding to use antibiotics } \\
\text { Intervention: decreased from } 40 \% \text { to }\end{array}$ \\
\hline
\end{tabular}




\begin{tabular}{|c|c|c|c|c|c|c|c|c|}
\hline & & & & & patients & $\begin{array}{l}\text { communication } \\
\text { Technic: two hours online } \\
\text { workshop }\end{array}$ & & $\begin{array}{l}27.1 \% \\
\text { Control: increased from } 36.8 \% \text { to } 65.5 \%\end{array}$ \\
\hline Pshetizky $2003^{37}$ & RCT & Israel & 3 months & $\begin{array}{l}3 \text { months } \\
\text { to } 4 \text { years }\end{array}$ & $\begin{array}{l}2 \text { primary } \\
\text { care clinics } \\
81 \text { parents }\end{array}$ & $\begin{array}{l}\text { Target: } \text { Parents } \\
\text { Approach: content: Patient- } \\
\text { clinician communication } \\
\text { Method } \text { : short explanation }\end{array}$ & $\begin{array}{l}\text { No brief explanation } \\
\text { given to parents }\end{array}$ & $\begin{array}{l}\text { Parents administered antibiotics to their } \\
\text { children in Intervention: } 37 \% \\
\text { Control: } 63 \%\end{array}$ \\
\hline $\begin{array}{l}\text { Regev-Yochay } \\
2011^{* 20}(4 \text { follow- } \\
\text { up time points } \\
\text { outcomes) }\end{array}$ & cRCT & $\begin{array}{l}\text { Israel/ } \\
50 \text { clusters }\end{array}$ & $\begin{array}{l}12,24,36,48 \\
\text { months }\end{array}$ & $<18$ years & $\begin{array}{l}\text { Primary care } \\
\text { pediatricians; } \\
97699 \\
\text { registered } \\
\text { children }\end{array}$ & $\begin{array}{l}\text { Target: Both clinician and } \\
\text { parents } \\
\text { Approach to clinicians: } \\
\text { Yearl: peer leaders training } \\
\text { content: guideline ; } \\
\text { Technic: } 2 \text { days workshop, } \\
\text { Year2: content: } \text { Patient- } \\
\text { clinician communication ; } \\
\text { Technic: } \text { workshop Year3: } \\
\text { APR feedback; } \\
\text { Technic: } \text { workshop } \\
\text { to parents : leaflets/poster; }\end{array}$ & No intervention & $\begin{array}{l}\text { APRs reduced by } 22 \% \text { in the control } \\
\text { group, by } 40 \% \text { in the intervention group }\end{array}$ \\
\hline Taylor $2005^{8}$ & RCT & US & 12 months & $\begin{array}{l}<24 \\
\text { months }\end{array}$ & $\begin{array}{l}\text { Pediatricians } \\
\text { in Seattle } \\
\text { Parents of } 499 \\
\text { eligible } \\
\text { children }\end{array}$ & $\begin{array}{l}\text { Target: } \text { Parents } \\
\text { Approach: } \text { Videos }\end{array}$ & $\begin{array}{l}\text { Parents received } \\
\text { educational leaflets } \\
\text { regarding effective } \\
\text { injury prevention }\end{array}$ & $\begin{array}{l}\text { Total no. of prescriptions for antibiotics } \\
\text { in Intervention: } 2.2 \pm 2.6 \\
\text { Control: } 2.5 \pm 2.9\end{array}$ \\
\hline Wheeler $2001^{39}$ & $\begin{array}{l}\text { Non- } \\
\text { randomized } \\
\text { controlled } \\
\text { trial }\end{array}$ & US & 9 months & $<19$ years & $\begin{array}{l}5 \text { pediatric } \\
\text { practices; } \\
9 \text { physicians; } \\
771 \text { parents }\end{array}$ & $\begin{array}{l}\text { Target: } \text { Parents } \\
\text { Approach: } \text { Videos } \\
\text { Leaflets/posters }\end{array}$ & $\begin{array}{l}\text { A control video on the } \\
\text { dangers of stimulant } \\
\text { use played to parents } \\
\text { in the waiting areas; }\end{array}$ & $\begin{array}{l}\text { APR for viral infection reduced from } \\
6.8 \% \text { to } 4.2 \% \text { in the intervention }\end{array}$ \\
\hline
\end{tabular}

Note: * Studies in which the number of children were prescribed any antibiotics from both groups, as well as the total number of children in each group were recalculated after adjustment for design effect (DE). \# For CRCTs ICCs reported, we estimated from similar study as supported by the evidences from Adams et al. in their article "Patterns of intra-cluster coORelation from primary care research to inform study design and analysis". 
Table 2. Summary of risk of bias of included studies $(n=12)$

\begin{tabular}{|c|c|c|c|c|c|c|c|c|}
\hline Study ID & $\begin{array}{l}\text { Sequence } \\
\text { generation }\end{array}$ & $\begin{array}{c}\text { Allocation } \\
\text { concealment }\end{array}$ & $\begin{array}{c}\text { Blinding participants and } \\
\text { personnel }\end{array}$ & $\begin{array}{c}\text { Blinding } \\
\text { of outcome } \\
\text { assessment }\end{array}$ & $\begin{array}{c}\text { Incomplete } \\
\text { outcome } \\
\text { data }\end{array}$ & $\begin{array}{c}\text { Selective } \\
\text { outcome } \\
\text { reporting }\end{array}$ & $\begin{array}{c}\text { Other } \\
\text { bias }\end{array}$ & $\begin{array}{c}\text { Summary } \\
\text { of } \\
\text { risk of bias }\end{array}$ \\
\hline Gerber 2013 & + & + & - & - & $?$ & + & $?$ & Low risk \\
\hline Gjelstad 2013 & + & + & $?$ & $?$ & + & $?$ & + & Low risk \\
\hline Juzych 2005 & - & + & + & $?$ & + & + & $?$ & High risk \\
\hline Esmaily 2010 & - & + & + & + & + & + & + & Low risk \\
\hline Pshetizky 2003 & + & + & + & $?$ & + & - & + & Low risk \\
\hline Taylor 2005 & + & + & + & ? & + & + & $?$ & Low risk \\
\hline Wheeler 2001 & - & - & - & $?$ & + & - & - & High risk \\
\hline Legare 2012 & + & + & - & + & + & - & $?$ & Low risk \\
\hline Francis 2009 & + & + & - & + & + & + & + & Low risk \\
\hline Gonzales 2005 & - & + & - & $?$ & + & + & $?$ & High risk \\
\hline $\begin{array}{l}\text { Regev-Yochay } \\
2011\end{array}$ & + & $?$ & - & $?$ & + & + & + & Low risk \\
\hline Finkelstein 2001 & + & + & + & $?$ & + & + & + & Low risk \\
\hline
\end{tabular}


Table 3. Results of meta-analysis of all included studies

\begin{tabular}{|c|c|c|c|c|}
\hline \multirow[b]{2}{*}{ Subgroup } & \multirow[b]{2}{*}{ No of study } & \multirow[b]{2}{*}{ OR $(95 \% \mathrm{CI})$} & \multicolumn{2}{|c|}{ Heterogeneity } \\
\hline & & & $\mathrm{I}^{2}$ & $\mathrm{p}$ \\
\hline Overall & $12 *$ & $0.65(0.49,0.86)$ & $66 \%$ & $<0.001$ \\
\hline \multicolumn{5}{|l|}{ Study target } \\
\hline Clinicians & 4 & $0.88(0.67,1.16)$ & $73 \%$ & 0.010 \\
\hline Parents & 3 & $0.50(0.10,2.51)$ & $80 \%$ & 0.007 \\
\hline Both & 5 & $0.52(0.34,0.79)$ & $50 \%$ & 0.009 \\
\hline \multicolumn{5}{|l|}{ Study design } \\
\hline cRCT & 9 & $0.56(0.41,0.78)$ & $74 \%$ & $<0.001$ \\
\hline Non-R control trial & 3 & $0.84(0.61,1.17)$ & $0 \%$ & 0.551 \\
\hline \multicolumn{5}{|l|}{ Follow-up duration } \\
\hline 1-6 months & 6 & $0.62(0.43,0.90)$ & $77 \%$ & $<0.001$ \\
\hline 7-12 months & 6 & $0.59(0.45,0.79)$ & $17 \%$ & 0.300 \\
\hline \multicolumn{5}{|l|}{$\begin{array}{l}\text { Intervention } \\
\text { intensity }\end{array}$} \\
\hline$<1$ day & 9 & $0.52(0.33,0.81)$ & $66 \%$ & 0.04 \\
\hline
\end{tabular}




\begin{tabular}{|c|c|c|c|c|}
\hline $\begin{array}{l}\geq 1 \text { day } \\
\text { Intervention } \\
\text { method }^{(a}\end{array}$ & 3 & $0.79(0.64,0.98)$ & $50 \%$ & 0.13 \\
\hline Face to face training & 6 & $0.77(0.65,0.92)$ & $36 \%$ & 0.160 \\
\hline $\begin{array}{l}\text { Non face to face } \\
\text { training }\end{array}$ & 3 & $0.38(0.21,0.70)$ & $44 \%$ & 0.170 \\
\hline \multicolumn{5}{|l|}{ ICC report * } \\
\hline ICC reported & 4 & $0.52(0.33,0.84)$ & $76 \%$ & 0.006 \\
\hline No ICC reported & 5 & $0.81(0.67,0.98)$ & $13 \%$ & 0.330 \\
\hline \multicolumn{5}{|l|}{ Study year } \\
\hline $2000 \mathrm{~s}$ & 7 & $0.59(0.35,1.00)$ & $66 \%$ & 0.007 \\
\hline $2010 \mathrm{~s}$ & 5 & $0.66(0.49,0.89)$ & $72 \%$ & 0.006 \\
\hline \multicolumn{5}{|l|}{ Clinical settings } \\
\hline Pediatric clinic & 4 & $0.61(0.47,0.79)$ & $0 \%$ & 0.470 \\
\hline Non-pediatric clinic & 8 & $0.60(0.43,0.85)$ & $74 \%$ & $<0.001$ \\
\hline
\end{tabular}

${ }^{*}$ ICC report studies only included the cluster studies. ${ }^{@}$ Intervention method used only for the studies targeting clinicians. 
Figure 1. Summary of included and excluded relevant articles in the review process.

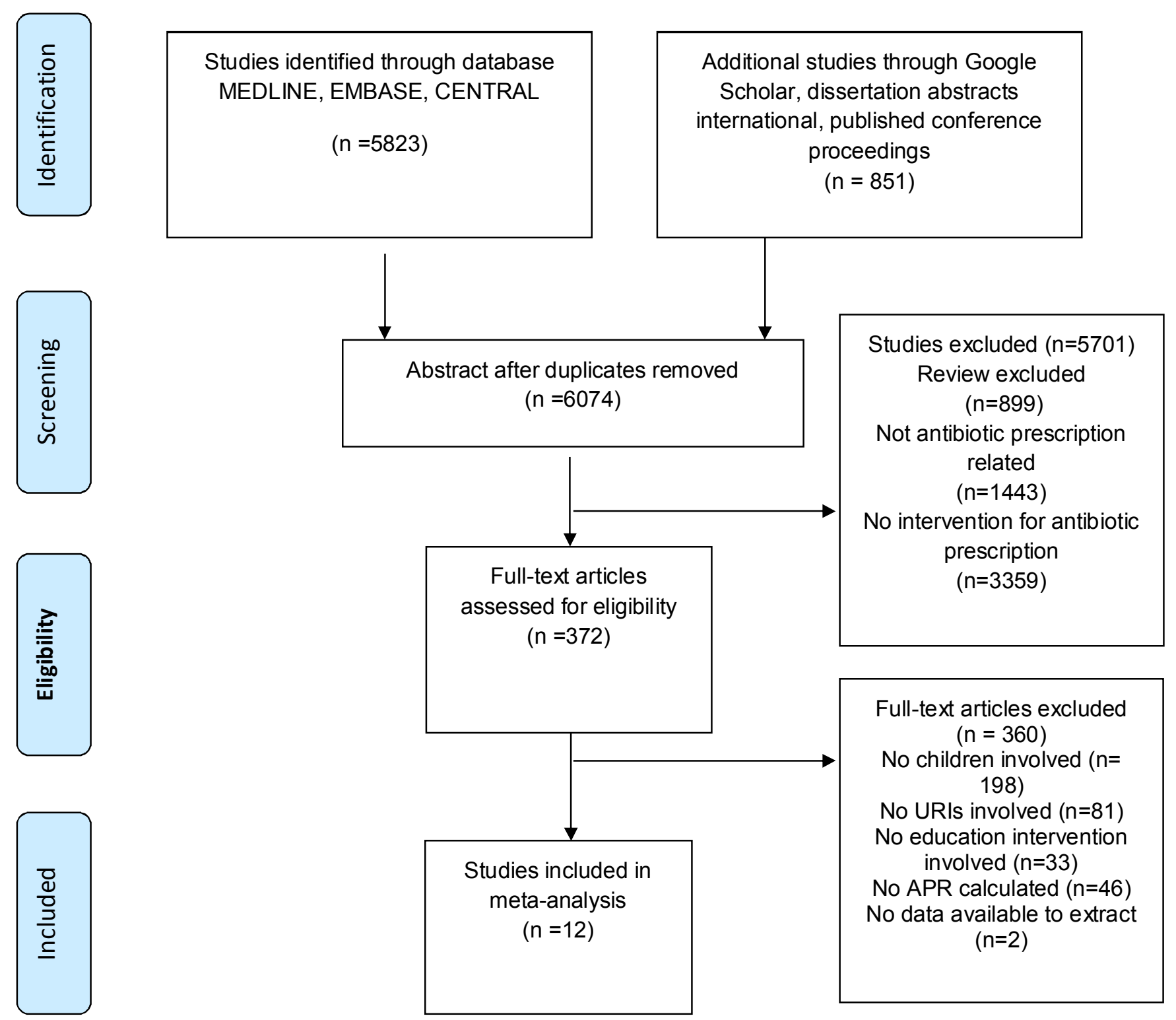

Note: CENTRAL $=$ the Cochrane Central Register of Controlled Trials. 
Figure 2. Pooled relative risk (OR) and 95\% confidence interval (CI) for reducing antibiotic prescription on childhood URIs

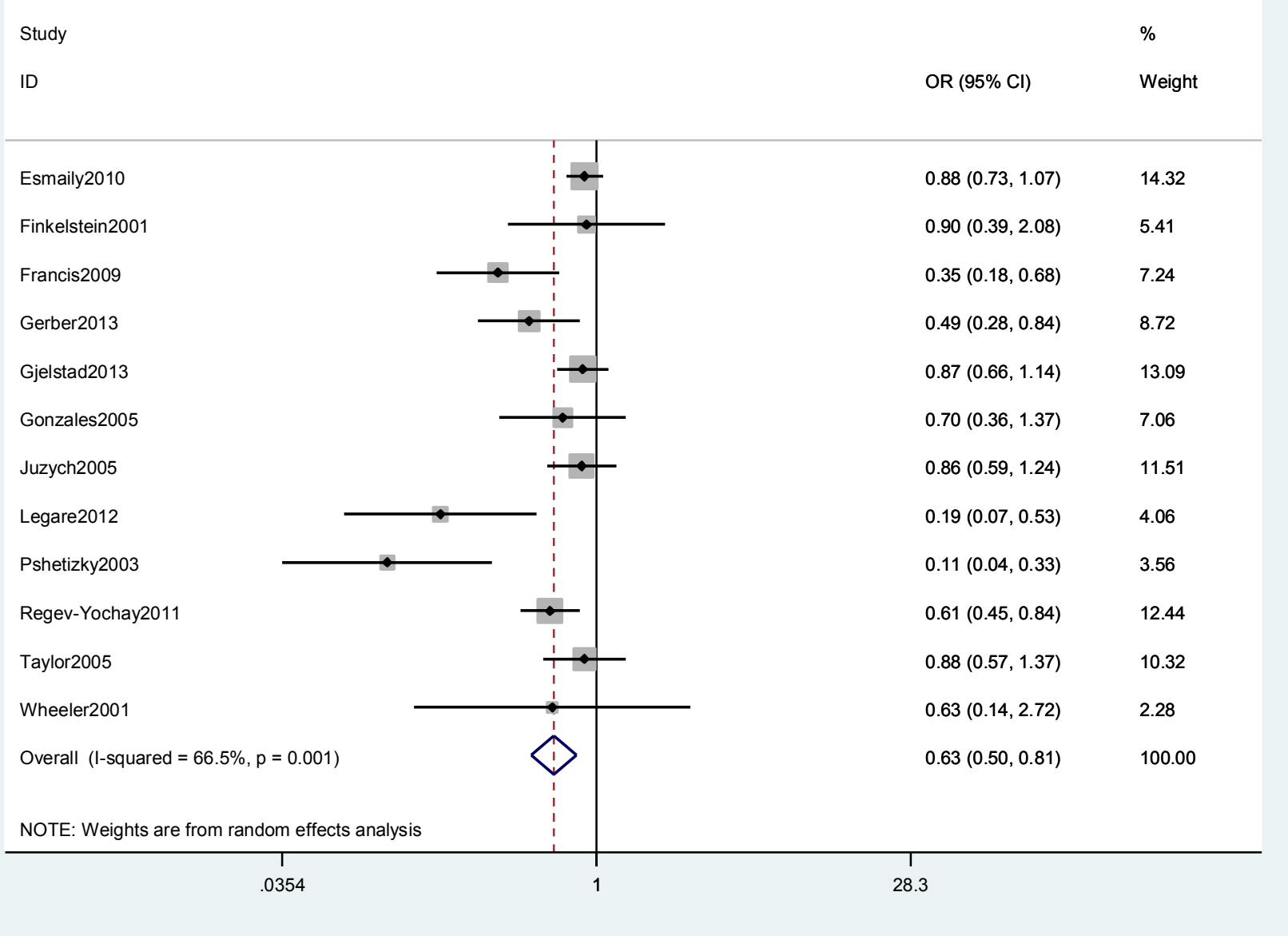

Figure 3. Forest plot results across different intervention types for clinicians and parents. 


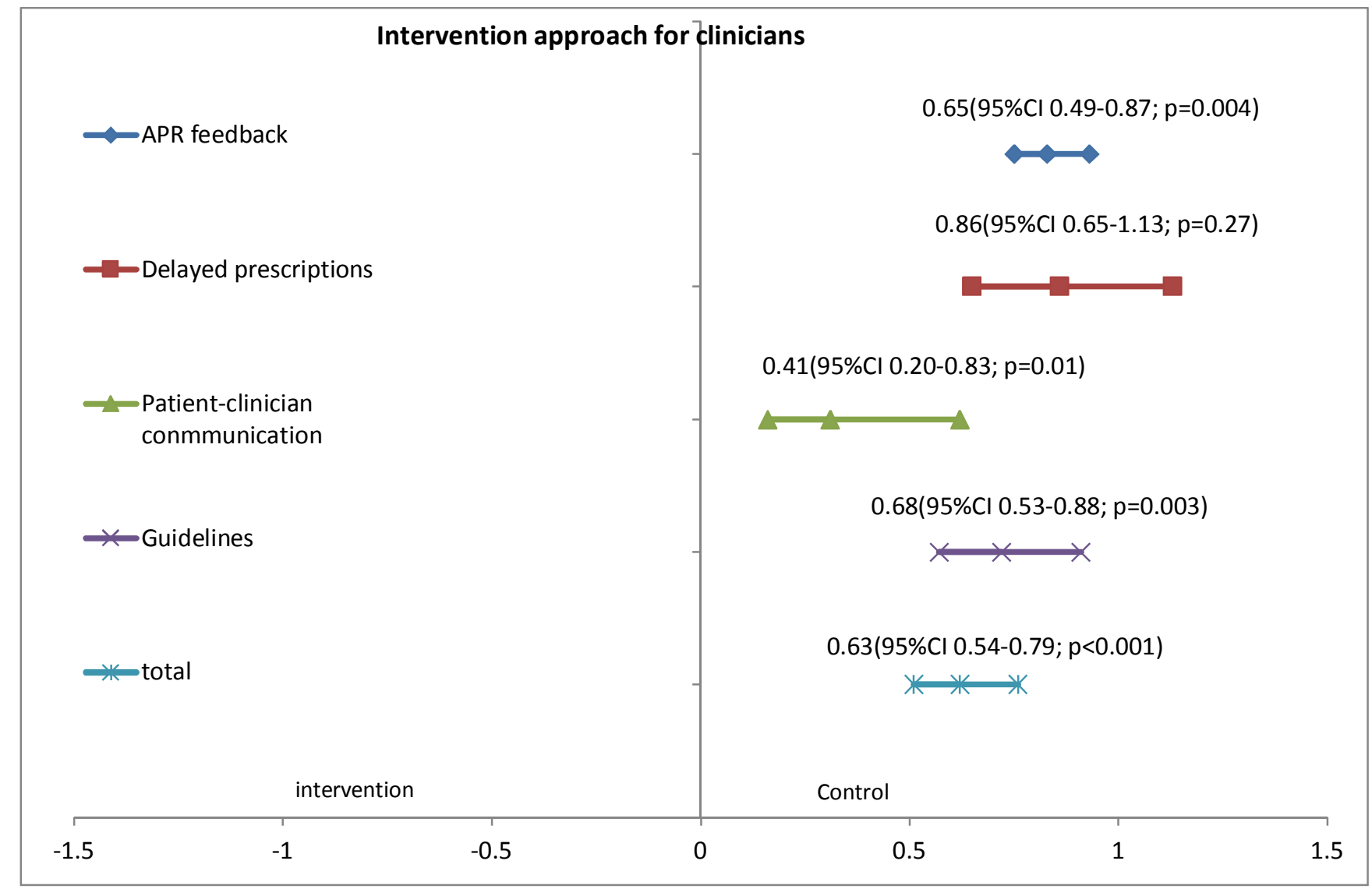

$p=$ test for overall effect. 


Intervention approach for parents
communication
intervention
- Videos

$p=$ test for overall effect. 


\section{References}

1. WHO, Promoting rational use of medicines: core components. . Secondary WHO, Promoting rational use of medicines: core components. 2002

2. Alves Galvao MG, Rocha Crispino Santos MA, Alves da Cunha AJ. Antibiotics for preventing suppurative complications from undifferentiated acute respiratory infections in children under five years of age. The Cochrane database of systematic reviews 2014;2:Cd007880.

3. Andrews T, Thompson M, Buckley DI, et al. Interventions to influence consulting and antibiotic use for acute respiratory tract infections in children: a systematic review and meta-analysis. PloS one 2012;7(1):e30334.

4. Irwin A, Sharland M. Measuring antibiotic prescribing in hospitalised children in resource-poor countries: a systematic review. Journal of paediatrics and child health 2013;49(3):185-92.

5. Ilic K, Jakovljevic E, Skodric-Trifunovic V. Social-economic factors and irrational antibiotic use as reasons for antibiotic resistance of bacteria causing common childhood infections in primary healthcare. European journal of pediatrics 2012;171(5):767-77.

6. Yu M, Zhao G, Stalsby Lundborg C, et al. Knowledge, attitudes, and practices of parents in rural China on the use of antibiotics in children: a cross-sectional study. BMC infectious diseases 2014;14(1):112.

7. Arnold SR, Straus SE. Interventions to improve antibiotic prescribing practices in ambulatory care. The Cochrane database of systematic reviews 2005(4):Cd003539.

8. Taylor JA, Kwan-Gett TS, McMahon EM, Jr. Effectiveness of a parental educational intervention in reducing antibiotic use in children: a randomized controlled trial. The Pediatric infectious disease journal 2005;24(6):489-93.

9. Spurling GK, Del Mar CB, Dooley L, et al. Delayed antibiotics for symptoms and complications of respiratory infections. The Cochrane database of systematic reviews 2004(4):Cd004417.

10. Ranji SR, Steinman MA, Shojania KG, et al. Interventions to reduce unnecessary antibiotic prescribing - A systematic review and quantitative analysis. Medical care 2008;46(8):847-62.

11. Davey P, Brown E, Charani E, et al. Interventions to improve antibiotic prescribing practices for hospital inpatients. The Cochrane database of systematic reviews 2013;4:Cd003543.

12. Schuetz P, Mueller B, Christ-Crain M, et al. Procalcitonin to initiate or discontinue antibiotics in acute respiratory tract infections. Cochrane Database of Systematic Reviews 2012(9).

13. Green JPHaS. Cochrane Handbook for Systematic Reviews of Interventions, 2008.

14. group cid. Data collection and reporting: A guide to inlcuding cluster randomized trials and participant randomized trials in intervention reviews Secondary Data collection and reporting: A guide to inlcuding cluster randomized trials and participant randomized trials in intervention reviews $2010 \mathrm{http} / / / \mathrm{cidg}$.cochrane.org/search/site/cluster randomized trial.

15. Borenstein M HL, Higgins JPT, Rothstein HRR. Introcution to Meta-Analysis: Complex Data Structures Secondary Introcution to Meta-Analysis: Complex Data Structures 2009.

http://www.meta-analysis.com/downloads/Meta-analysis Studies with multiple subgroups or outcomes.pdf.

16. Riley RD, Higgins JPT, Deeks JJ. Interpretation of random effects meta-analyses, 2011.

17. Deeks JJ, Higgins JPT, Altman DG. Analysing Data and Undertaking Meta-Analyses.

18. Finkelstein JA, Davis RL, Dowell SF, et al. Reducing antibiotic use in children: a randomized trial in 12 practices. Pediatrics 2001;108(1):1-7.

19. Gonzales R, Corbett KK, Leeman-Castillo BA, et al. The "minimizing antibiotic resistance in Colorado" project: impact of patient education in improving antibiotic use in private office practices. Health services research 2005;40(1):101-16.

20. Regev-Yochay G, Raz M, Dagan R, et al. Reduction in antibiotic use following a cluster randomized controlled multifaceted intervention: the Israeli judicious antibiotic prescription study. Clinical infectious diseases : an official publication of the Infectious Diseases Society of America 2011;53(1):33-41. 
21. Arroll B, Kenealy T, Kerse N. Do delayed prescriptions reduce antibiotic use in respiratory tract infections? A systematic review. Br J Gen Pract 2003;53(496):871-7.

22. Patel SJ, Larson EL, Kubin CJ, et al. A review of antimicrobial control strategies in hospitalized and ambulatory pediatric populations. Pediatr Infect Dis J 2007;26(6):531-7.

23. Yin X, Song F, Gong Y, et al. A systematic review of antibiotic utilization in China. The Journal of antimicrobial chemotherapy 2013.

24. Vodicka TA, Thompson M, Lucas $\mathrm{P}$, et al. Reducing antibiotic prescribing for children with respiratory tract infections in primary care: a systematic review. The British journal of general practice : the journal of the Royal College of General Practitioners 2013;63(612):e445-54.

25. Ranji SR, Steinman MA, Shojania KG, et al. Interventions to reduce unnecessary antibiotic prescribing: a systematic review and quantitative analysis. Medical care 2008;46(8):847-62.

26. Boonacker CW, Hoes AW, Dikhoff MJ, et al. Interventions in health care professionals to improve treatment in children with upper respiratory tract infections. International journal of pediatric otorhinolaryngology 2010;74(10):1113-21.

27. Thoolen B, de Ridder D, van Lensvelt-Mulders G. Patient-oriented interventions to improve antibiotic prescribing practices in respiratory tract infections: a meta-analysis. Health Psychology Review 2012;6(1):92-112.

28. Huang SS, Rifas-Shiman SL, Kleinman K, et al. Parental knowledge about antibiotic use: results of a cluster-randomized, multicommunity intervention. Pediatrics 2007;119(4):698-706.

29. Hemming K, Girling AJ, Sitch AJ, et al. Sample size calculations for cluster randomised controlled trials with a fixed number of clusters. BMC medical research methodology 2011;11:102.

30. Organization WH. Worldwide country situation analysis: response to antimicrobial resistance. Secondary Worldwide country situation analysis: response to antimicrobial resistance 29 April 2015. http://www.who.int/drugresistance/documents/situationanalysis/en/.

31. Esmaily HM, Silver I, Shiva S, et al. Can rational prescribing be improved by an outcome-based educational approach? A randomized trial completed in Iran. The Journal of continuing education in the health professions 2010;30(1):11-8.

32. Francis NA, Butler CC, Hood K, et al. Effect of using an interactive booklet about childhood respiratory tract infections in primary care consultations on reconsulting and antibiotic prescribing: a cluster randomised controlled trial. BMJ (Clinical research ed) 2009;339:b2885.

33. Gerber JS, Prasad PA, Fiks AG, et al. Effect of an outpatient antimicrobial stewardship intervention on broad-spectrum antibiotic prescribing by primary care pediatricians: a randomized trial. JAMA : the journal of the American Medical Association 2013;309(22):2345-52.

34. Gjelstad S, Hoye S, Straand J, et al. Improving antibiotic prescribing in acute respiratory tract infections: cluster randomised trial from Norwegian general practice (prescription peer academic detailing (Rx-PAD) study). BMJ (Clinical research ed) 2013;347:f4403.

35. Juzych NS, Banerjee M, Essenmacher L, et al. Improvements in antimicrobial prescribing for treatment of upper respiratory tract infections through provider education. Journal of general internal medicine 2005;20(10):901-5.

36. Legare $\mathrm{F}$, Labrecque $\mathrm{M}$, Cauchon $\mathrm{M}$, et al. Training family physicians in shared decision-making to reduce the overuse of antibiotics in acute respiratory infections: a cluster randomized trial. CMAJ : Canadian Medical Association journal = journal de l'Association medicale canadienne 2012;184(13):E726-34.

37. Pshetizky Y, Naimer S, Shvartzman P. Acute otitis media--a brief explanation to parents and antibiotic use. Family practice 2003;20(4):417-9.

38. Smabrekke L, Berild D, Giaever A, et al. Educational intervention for parents and healthcare providers leads to reduced antibiotic use in acute otitis media. Scandinavian journal of infectious diseases 2002;34(9):657-9.

39. Wheeler JG, Fair M, Simpson PM, et al. Impact of a waiting room videotape message on parent attitudes toward pediatric antibiotic use. Pediatrics 2001;108(3):591-6. 
